\title{
Galectin-3 and sST2 as Prognosticators for Heart Failure Requiring Extracorporeal Life Support: Jack n' Jill
}

\author{
Jianli Bi ${ }^{1,2}$, Vidu Garg 1,2,3,4(i) and Andrew R. Yates 1,2,3,*(D) \\ 1 Center for Cardiovascular Research, Nationwide Children's Hospital, Columbus, OH 43205, USA; \\ jianli.bi@nationwidechildrens.org (J.B.); vidu.garg@nationwidechildrens.org (V.G.) \\ 2 The Heart Center, Nationwide Children's Hospital, Columbus, OH 43205, USA \\ 3 Department of Pediatrics, The Ohio State University, Columbus, OH 43205, USA \\ 4 Department of Molecular Genetics, The Ohio State University, Columbus, OH 43205, USA \\ * Correspondence: ANDREW.YATES@nationwidechildrens.org
}

check for

updates

Citation: Bi, J.; Garg, V.; Yates, A.R Galectin-3 and sST2 as Prognosticators for Heart Failure Requiring Extracorporeal Life Support: Jack n' Jill. Biomolecules 2021, 11, 166. https://doi.org/10.3390/ biom11020166

Received: 8 January 2021

Accepted: 22 January 2021

Published: 27 January 202

Publisher's Note: MDPI stays neutral with regard to jurisdictional claims in published maps and institutional affiliations.

Copyright: (c) 2021 by the authors. Licensee MDPI, Basel, Switzerland. This article is an open access article distributed under the terms and conditions of the Creative Commons Attribution (CC BY) license (https:// creativecommons.org/licenses/by/ $4.0 /)$.

\begin{abstract}
Extracorporeal life support provides perfusion for patients with heart failure to allow time for recovery, function as a bridge for patients to heart transplantation, or serve as destination therapy for long term mechanical device support. Several biomarkers have been employed in attempt to predict these outcomes, but it remains to be determined which are suitable to guide clinical practice relevant to extracorporeal life support. Galectin-3 and soluble suppression of tumorigenicity-2 (sST2) are two of the more promising candidates with the greatest supporting evidence. In this review, we address the similarities and differences between galectin- 3 and SST2 for prognostic prediction in adults and children with heart failure requiring extracorporeal life support and highlight the significant lack of progress in pediatric biomarker discovery and utilization.
\end{abstract}

Keywords: extracorporeal life support; mechanical circulatory support; ECMO; VAD; galectin-3; sST2; heart failure

\section{Introduction}

Heart failure is a life-threatening condition in both adults and children and is associated with high mortality, morbidity and cost of care. The incidence of heart failure in the general population is $2000 / 100,000$ in adults [1,2] and 0.87-7.4/100,000 in children [3]. Extracorporeal life support (ECLS) including ventricular assist device (VAD) implantation and extracorporeal membrane oxygenation (ECMO) is required for patients with advanced or end-staged heart failure either as destination therapy or as a bridge-to-transplantation therapy. Over 25,000 adult and 21,000 children (including neonatal and pediatric patients) cases of ECLS were required globally, for cardiac indications, in the past 30 years. The overall survival rate was 59\% in adults and $68 \%$ in children [4]. Limited literature is available to document prognostic markers for myocardial recovery in patients with refractory heart failure requiring circulatory support after decades of research. Early attempts to identify a biomarker to predict outcomes of ECLS have followed the evolution of cardiac biomarker testing utilizing brain natriuretic peptide (BNP) [5] and its N-terminal fragment, NT-proBNP [6] in the early 2000s through the recognition of cardiac troponin 10 years later [7]. The early decrease in BNP level is indicative of ventricular unloading during ECLS but the rebound in BNP level after decannulation suggests BNP is not an ideal biomarker to predict complete normalization of cardiac function [5]. Other heart failure related biomarkers which have been explored in patients who underwent ECLS include dynamic BNP [8], galectin-3 [9], ST2 [10], matrix metalloproteinase-9 (MMP-9) [11], tissue inhibitors of metalloproteinase-1 (TIMP-1) [11], MMP-2 [11,12], osteopontin [13], MR-proANP [14], proADM [14], and copeptin [14]. The above-depicted biomarkers may assist to predict outcomes of heart failure requiring ECLS under limited circumstances and their identifications are summarized in Table 1 . Nevertheless, no single blood biomarker 
has demonstrated superiority to predict outcomes of heart failure requiring ECLS, but galectin-3 and ST2 have been promising and may be worthwhile to study further [15]. Unfortunately, a decade has passed with no significant progress in our ability to predict outcomes in patients with heart failure requiring ECLS. The failure of a single biomarker and/or single time-point measurement suggest that one may need to employ a combination of biomarkers with associated dynamic changes to predict outcomes in this context. Recently, there is growing interest in the use of galectin-3 and soluble suppression of tumorigenicity-2 (sST2) as potentially reliable prognostic markers [16]. These recent studies have demonstrated that SST2 provides independent predictive value beyond NT-proBNP and cardiac troponin for all-cause cardiovascular mortality in adult patients with chronic heart failure, which may be one explanation for this evolution [17]. Additionally, high levels of galectin-3 and BNP are often found before implantation of a ventricular assist device in patients with terminal heart failure, but elevated BNP failed to identify patients who would not survive VAD support. This prompted interest in galectin-3 levels which could better predict outcomes [18]. If proved in additional studies, the early prognostic value of gelactin-3 and sST2 to accurately identify patients destined for unfavorable recovery after ECLS implementation could provide a critical opportunity to modify treatment algorithms to a more personalized therapeutic approach to improve outcomes. Galectin-3 and SST2 are linked to the development of fibrosis which prevents recovery of myocardial function and may indicate severity of the disease state. In this review, we provide an overview of the recent clinical interpretation of galectin-3 and sST2 and emphasize their similarities and differences for the prognostic prediction of heart failure requiring ECLS. We also address the significant lack of data on galectin-3 and sST2 in pediatric patients undergoing ECLS and attempt to raise awareness about the novel utilization of galection-3 and SST2 as prognosticators in the pediatric population.

Table 1. Identification of heart failure-related biomarkers for patients undergoing ECLS.

\begin{tabular}{|c|c|}
\hline Biomarkers & Identification \\
\hline Brain natriuretic peptide (BNP) & \multirow{11}{*}{$\begin{array}{c}\text { cyclic peptide hormone containing disulfide bridge } \\
\text { N-terminal fragment of BNP } \\
\text { calcium-regulatory protein } \\
\text { carbohydrate-binding protein with a single } \\
\text { carbohydrate recognition domain and a } \\
\text { unique N-terminus } \\
\text { one of member of Matrix metalloproteinases (zinc- } \\
\text { and calcium-dependent endopeptidases) } \\
\text { soluble suppression of tumorigenicity } 2 \\
\text { protein containing an N- and C-terminal domain of } \\
125 \text { and } 65 \text { amino acids, respectively, with each } \\
\text { containing three conserved disulfide bonds } \\
\text { extracellular structural protein } \\
\text { mid-regional fragment of proANP (ANP precursor) } \\
\text { long-acting vasodilatory peptide } \\
\text { 39-amino-acid glycopeptide and the C-terminal } \\
\text { portion of provasopressin }\end{array}$} \\
\hline NT-proBNP & \\
\hline Troponin & \\
\hline Galectin-3 & \\
\hline MMP-2 and 9 & \\
\hline sST2 & \\
\hline Tissue inhibitors of metalloproteinases-1 (TIMP-1) & \\
\hline Osteopontin & \\
\hline MR-proANP & \\
\hline proADM & \\
\hline Copeptin & \\
\hline
\end{tabular}

\section{Galectin-3}

Galectin-3 is a member of the galectins family of carbohydrate-binding proteins with specificity for $\mathrm{N}$-acetyllactosamine (LacNAc)-containing glycoproteins, and the only known one with a single carbohydrate recognition domain and a unique $N$-terminus $[19,20]$. It is a $30 \mathrm{kDa}$ molecule encoded by the LGALS3 gene that is located on chromosome 14, locus q21-q22 [21]. It is mainly secreted by macrophages and regulates basic cellular functions including growth, proliferation, differentiation and inflammation [22-25] and importantly has been found to play a role in cardiac fibrosis [26,27]. Evidence that links Galectin-3 to pathogenesis of heart failure has not been fully elucidated. However, recent studies have suggested that galectin-3 can help to predict prognosis of heart failure and adverse events in various clinical settings such as ST elevation myocardial infraction [28], congenital heart disease patients with a Fontan circulation [29] and survivors of out-of-hospital cardiac 
arrest [30]. In addition, its levels have correlated with morbidity and mortality in patients with heart failure [31-34]. Higher values ( $>15.3 \mathrm{ng} / \mathrm{mL}$ ) of galectin-3 have been reported to show a correlation with the severity of heart failure [35].

VAD implantation is a standard ECLS modality for adult patients with end-staged heart failure. A retrospective study [36] including 57 adult patients with severe heart failure (NYHA Class IIIB-IV) who underwent VAD implantation found that a lower galectin3 concentration $(<30 \mathrm{ng})$ at the time of VAD implantation was associated with better prognosis when compared to an elevated concentration $(>30 \mathrm{ng} / \mathrm{mL}) 2$ years after VAD implantation. Similarly, the plasma galectin-3 concentration immediately before VAD implantation in patients who did not survive ECLS was significantly higher than that in those who were weaned from VAD support or received heart transplantation $(18.8 \mathrm{ng} / \mathrm{mL}$ vs. $15.3 \mathrm{ng} / \mathrm{mL}$ ). An additional study in adults noted that a higher galectin-3 concentration $(>17 \mathrm{ng} / \mathrm{mL}$ ) was associated with poor survival in low- or medium-risk VAD patients. However, the galectin-3 concentration was not a predictor in high-risk VAD patients [36]. These controversial results suggest that a single biomarker is limited in its ability to predict a clinically significant outcome, which is likely the result of multiple factors. A combination of the biomarkers may be required to eliminate this limitation. It is important to note that there is discrepancy in defining the clinically important cut-off values for galectin-3 in the above-mentioned studies, where the at-risk population was reported to be greater than 17 or $30 \mathrm{ng} / \mathrm{mL}[36,37]$. The underlying reasons for this are unknown but may be related to differences in patient populations or techniques. Importantly, the galectin-3 concentrations were determined by different commercial kits in the studies above.

There is significantly less literature regarding galectin- 3 in pediatric patients as compared to adults. Similar to adults, the galectin-3 concentration has been reported to be higher in children (median age: 9 years) with chronic heart failure than those (median age: 8.5 years) with normal heart function $(9.46 \pm 5.43 \mathrm{vs} .1 .5 \pm 0.66 \mathrm{ng} / \mathrm{mL}, p<0.001)$. The increased galectin-3 concentration is associated with the severity of heart failure and can be reduced by spironolactone treatment [38]. The reduction of galectin-3 after spironolactone administration may be related to improvement of heart function. This suggests that galactin-3 may be used as a marker of disease severity in children with chronic heart failure and could potentially guide response to treatment in pediatric patients. In terms of the clinical value of galectin-3 for prognosis prediction in pediatric patients, a prospective study including 76 children with chronic heart disease has demonstrated that galectin-3 is positively associated with the Ross classification score for pediatric heart failure and plays an important role in early diagnosis and prognosis prediction [39]. The studies regarding application of galectin-3 in pediatric patients with heart failure requiring ECLS are quite scarce compared to adult patient populations and all the studies only evaluate VAD patients (Table 2).

Table 2. Application of galectin-3 in adult and pediatric patients with heart failure requiring ECLS.

\begin{tabular}{|c|c|c|c|c|c|}
\hline Reference & Year & Adult/Peds & $\mathbf{N}=$ & Population & Major Finding \\
\hline [17] & 2008 & Adult & 40 & VAD & $\begin{array}{l}\text { Higher Gal-3 pre implant associated with mortality }(\mathrm{n}=15) \\
\text { compared to bridged to transplant }(\mathrm{n}=25)(13.4+3.6 \mathrm{ng} / \mathrm{mL} \text { vs. } \\
\qquad 9.6+5.2 \mathrm{ng} / \mathrm{mL}, p<0.02)\end{array}$ \\
\hline [36] & 2013 & Adult & 175 & VAD & $\begin{array}{l}\text { Higher Galectin-3 levels }(>17 \mathrm{ng} / \mathrm{mL}) \text { increased mortality for } \\
\text { low / medium risk VAD patients }\end{array}$ \\
\hline [40] & 2015 & Adult & 25 & VAD & Gal-3 remains elevated after continuous flow VAD placed \\
\hline [41] & 2015 & Adult & 37 & VAD & Gal-3 decreases during LVAD support \\
\hline$[35]$ & 2016 & Adult & 57 & VAD & $\begin{array}{l}\text { Galectin-3 levels }>30 \mathrm{ng} / \mathrm{mL} \text { are associated with lower survival } \\
\text { post-LVAD placement }(76.5 \% \text { versus } 95.0 \% \text { at } 2 \text { years, } p=0.009)\end{array}$ \\
\hline [15] & 2018 & Both & $\begin{array}{l}7 \text { adult } \\
12 \text { pediatric }\end{array}$ & VAD & Children similar Galectin-3 levels as adults post VAD \\
\hline
\end{tabular}




\section{3. sST2}

SST2 is a circulating form of suppression of tumorigenicity-2 (ST2) glycoprotein that is a member of the interleukin 1 receptor family. The ST2 glycoprotein is encoded by the IL1RL1 gene located in the chromosome 2q12. It serves as the receptor for IL-33, an IL-1-like cytokine that can be secreted by living cells in response to cell damage [42]. IL-33 exerts its cardioprotective function by reducing cardiac fibrosis and inflammation [43]. sST2 can eliminate this cardioprotective function by acting as a decoy to IL-33 [43] and thus is considered an indicator of adverse outcome [44] and a prognostic predictor for heart disease without ECLS [45-47]. Moreover, a pooled study including 1800 elderly patients who underwent cardiac surgery has demonstrated that a higher SST2 level is a soothsayer for an increased incidence of cardiovascular events or mortality [48]. The prognostic value of sST2 in heart failure may benefit physicians by allowing them a way to identify patients with a high risk of adverse events early in their course of care.

sST2 has been much less studied in ECLS than galactin-3. One study by Tseng et al. [49] showed that the sST2 level was significantly increased in $95 \%$ of adult patients, aged 17 to 68 years before VAD implantation (the median sST2 level was $74.2 \mathrm{ng} / \mathrm{mL}$ with the normal value defined as $<35 \mathrm{ng} / \mathrm{mL}$ ). sST2 then significantly decreased during VAD support and normalized after 6 months $(29.5 \mathrm{ng} / \mathrm{mL})$, with the maximum drop occurring by 3 months (no significant decrease thereafter). They concluded that the high sST2 levels predicted poorer outcomes in patients on conventional treatments and was a consequence of endstage heart failure. Their data suggest that the SST2 level was a useful parameter to monitor therapy. However, they failed to show whether high sST2 levels at any timepoint can predict outcomes post implantation. Similar to galectin 3, there are limited studies (Table 3) in children and will be discussed in a later section.

Table 3. Application of sST2 in adult and pediatric patients with heart failure requiring ECLS.

\begin{tabular}{cccccc}
\hline Reference & Year & Adult/Peds & N $=$ & Population & Major Finding \\
\hline$[41]$ & 2015 & Adult & 37 & VAD & sST2 elevated in VAD patients and normalized after 6 months; not \\
p predictive of outcomes
\end{tabular}

\section{Dynamic Changes of Galectin-3 and sST2 in Adult and Children Undergoing ECLS: Similarities and Differences}

As described above, galectin-3 and SST2 have been used alone or concomitantly as biomarkers in several studies regarding heart failure with or without ECLS [28,31,46]. Galectin-3 and sST2 are similar in that both can reflect severity of myocardial damage (presumably related to fibrosis) to thereby predict prognosis. However, they act differently in the development of heart failure. As shown in Figure 1, in response to cardiac injury, activated macrophages produce galectin- 3 which is then thought to regulate phenotypic change of cardiac fibroblasts from the resting to the activated status [50], whereas sST2 binds to IL33 to block the binding of IL33 to ST2 on cardiomyocytes. Binding of IL33 to cardiomyocyte membrane ST2 results in the initiation of IL33/ST2 pathway which then evokes an antihypertrophic and antifibrotic function [51].

Data regarding the similarities and differences of galectin- 3 and SST2 between adults and children at baseline and while undergoing ECLS are extremely limited. To date, only one study [16] is available to compare the dynamic changes of galectin-3 and sST2 in adults and children with heart failure requiring VAD. The investigators demonstrated that the galectin-3 and sST2 from adults and children show a similar trend, climbing up one day after VAD implant, and plunging down two days after VAD implant and to baseline levels in 30 days (Figure 2, redrawn based on the data in the study). The circulating level of sST2 is significantly higher in children than in adults at every time points (Figure 2A). In contrast, the circulating level of galectin-3 is not different (Figure 2B). These data indicate 
differing responses of galectin-3 and sST2 with VAD implant in children compared to adults. The changes of galectin-3 and SST2 in day 1 and 2 may be a result of macrophage activation related to inflammatory processes surrounding surgical implantation of a VAD. Their differences may indicate varying degree of macrophage activation between children and adults.

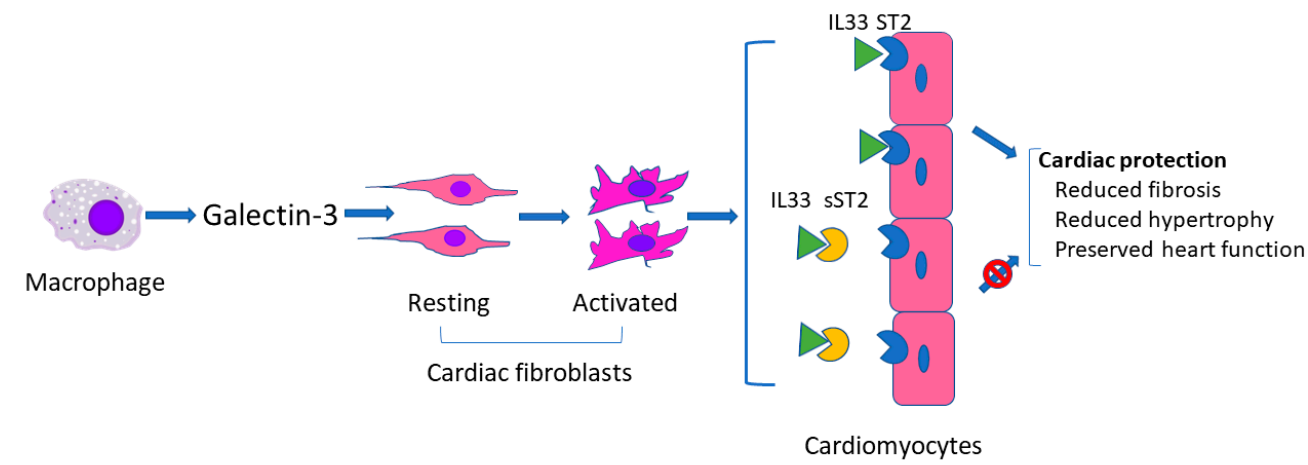

Figure 1. Schematic of possible mechanism of galectin 3 and sST2 in heart failure.

A

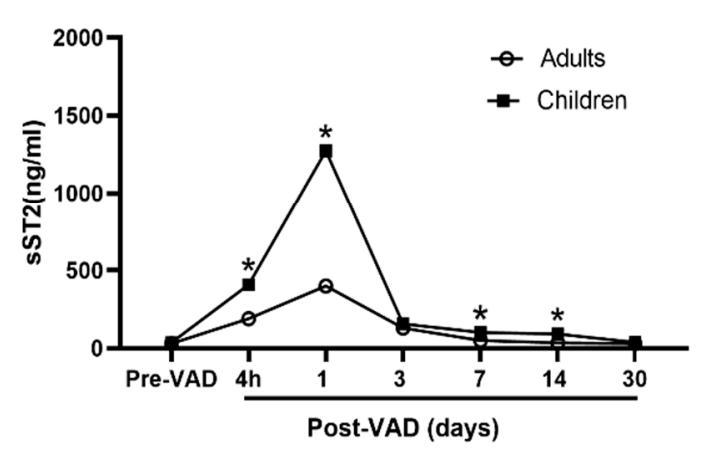

B

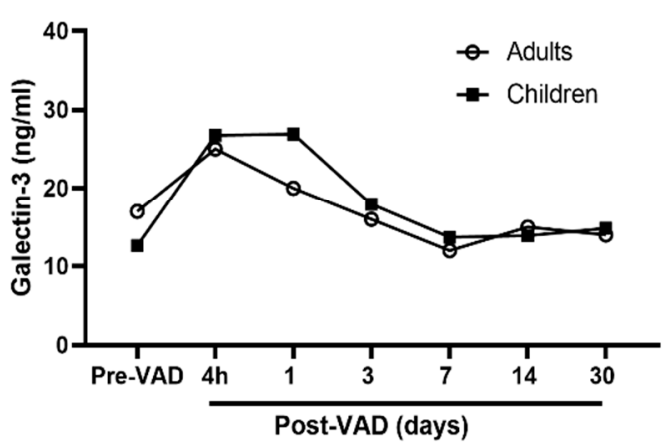

Figure 2. Comparison of sST2 and galectin-3 between adults and children undergoing VAD. Redrawn based upon data reported in [15]. (A) Significantly higher circulating level of sST2 in children than in adults at every time points; (B) No difference in the circulating level of galectin-3.

To the best of our knowledge, no data are available to describe the trend and prognostic value of plasma or serum galectin-3 and sST2 in children or adults undergoing VA-ECMO for cardiac failure. VA-ECMO use is much more common in pediatric patients than VAD implantation compared to adults, and this deficit requires further studies to fill this gap of our knowledge.

\section{Feasibility of Using Galectin-3 and sST2 as Prognosticators}

The general principles to evaluate feasibility of a biomarker include the following: (a) it is easily obtained, (b) highly reproducible, (c) it is biologically plausible and (d) impacts care. Obtaining a blood sample is part of the postoperative routine and does not involve technically complicated procedures. The measurement of plasma or serum galectin-3 and sST2 would not be a significant burden to a current clinical protocol. Second, a biomarker should be scientifically reproducible and financially affordable. The assays for human plasma/serum galectin-3 and sST2 have been commercially available for clinical and research purposes [52]. The stability in vitro, biological variation, and reference values for galectin-3 and sST2 have been previously summarized in a comprehensive review [52] that demonstrates these 2 biomarkers should be clinically reproducible across laboratories. Lastly, studies have highlighted the potential role of galectin-3 and sST2 in the prediction of prognosis in many clinical settings to impact care as discussed above. 
Unlike the traditional biomarkers including natriuretic peptides and troponins, sST2 is relatively independent from age, prior diagnosis of HF, body mass index, ischemic type of $\mathrm{HF}$, or atrial fibrillation [53]; galectin-3 is thought to reflect myocardial remodeling and appears to be dynamical biomarker in long-term ECLS. However, galectin-3 is also associated with various fibrotic conditions (liver and lung) [54,55] and this could be a potential confounder in developing treatment strategies.

\section{Possibility to Use Galectin-3 and sST2 as Indicators to Adjust Medical Regimens or as Therapeutic Targets}

Natriuretic peptide-guided therapy in chronic heart failure has been reported in some studies with promising outcomes [56-58], whereas other studies have reported uncertain results $[59,60]$. The controversies suggest inadequate power to draw a conclusion in biomarker-guided treatment for heart failure. Galectin-3 and sST2 have not yet been sufficiently studied in guiding treatment in patients with heart failure who receive pharmacotherapy, not to mention in patients with heart failure who require ECLS.

As described in Figure 1, galectin-3 is an initiator of the inflammation process in heart failure. Targeting galectin- 3 may be a potential therapy to improve the outcomes of heart failure. Extracellular and intracellular small-molecule galectin-3 inhibitors (3,3'Bis-(4-aryltriazol-1-yl) thiodigalactosides [61] and galectin-3 inhibitor compound 2H [62]) have been investigated [63]. The availability of these inhibitors has laid a foundation for further study of a targeted treatment of galectin-3. Interestingly, modified citrus pectin (a dietary supplement) has been used as an inhibiter of galectin- 3 to block cardiac injury that is induced by acute kidney injury via the galectin-3 pathway [64] and may provide an easy initial molecule for clinical trials.

sST2 concentrations have been used to identify patients with chronic heart failure who may particularly benefit from $\beta$-adrenergic blocker therapy [47]. At cutoff values of sST2 level of $35 \mathrm{ng} / \mathrm{mL}$ and with a metoprolol dose of $50 \mathrm{mg}$ daily (defined as a high dose in the study), patients with low sST2/high-dose BB had the lowest cardiovascular event rate ( 0.53 events); those with low sST2/low-dose $\beta$-adrenergic blocker, or high sST2/high-dose $\beta$-adrenergic blocker had intermediate outcomes (0.92 and 1.19 events); patients with high sST2 treated with low-dose $\beta$-adrenergic blocker had the highest cardiovascular event rate (2.08 events).

In terms of a targeted therapy on sST2 itself, no chemical compound serving as a sST2 antagonist has been reported. Instead, an anti-ST2 mAb has been used to block the interaction between sST2 and IL33 to release free IL33 [65]. The concern is that the anti-ST2 mAb can block the cell membrane ST2 [66] to thereby suppress the IL33/ST2 pathway that is considered cardioprotective.

Neither galectin-3 and/or sST2 has been examined as guides for adjusting medical management for heart failure in pediatric patients, and thus the role of galectin-3 and / or sST2 as a guide to therapeutic decision-making remains to be established. Additionally, within the pediatric patient population, the use of galectin-3 and/or sST2 as a biomarker for risk stratification in children undergoing ECLS with VAD has not been reported, and the impact of VA-ECMO on galectin-3 and sST2 remains unknown.

\section{Conclusions}

Undergoing ECLS creates a complex clinical situation with challenges related to early and accurate prediction of prognosis, particularly in pediatric patients. To distinguish patients who will improve and those who will not early during ECLS is imperative as would not only assist the medical team to formulate an optimal care plan but may also provide a scientific justification to initiate ethical discussions with the patient's family. Galectin-3 and sST2 have come to prominence as early prognosticators in adult ECLS patients since other biomarkers (BNP [67], NT-proBNP, TnIc, MR-proANP, proADM, and copeptin [14]) have failed to show significance. To discern the complex differences of biomarkers, further studies are needed to investigate the use of a single biomarker (galectin-3 or sST2) versus combined biomarkers (galectin-3, sST2 and/or other markers) which has been done for 
adult with heart failure but not yet for ECLS patient $[40,41,68]$, and sampling at single time point versus multiple time points in ECLS patients.

Beyond protein biomarkers, circulating microRNAs are emerging as intriguing, predictive biomarkers for heart failure. These microRNAs are attractive candidates due to their known biologic roles in reverse remodeling $[69,70]$ and their ability to discriminate heart failure of different etiologies due to their cell-type specific expression [71]. Akat et al. demonstrated a significant increase in heart-specific circulating microRNAs in patients with advanced heart failure that completely reversed 3 months after initiation of VAD support [72]. This suggests that the decreased levels of circulating microRNAs are associated with favorable outcomes following VAD support. While no data are available to show a link between circulating microRNAs and prognosis of heart failure requiring ECLS, the potential value of circulating microRNAs in predicting ECLS outcomes in the near future should not be overlooked and requires further investigation in pediatric patients as well.

Based on the currently available published data, we expect that the combined galectin3 and sST2 biomarkers, followed serially, will be beneficial in guiding management of children undergoing ECLS in the future but additional work is needed to identify other novel biomarkers (e.g., microRNAs), and biomarker response to other forms of ECLS (such as VA-ECMO) that may serve to improve the care of the pediatric patient population.

Author Contributions: Conceptualization, A.R.Y., J.B. and V.G.; methodology, A.R.Y. and J.B.; writing-original draft preparation, J.B.; writing-review and editing, A.R.Y., V.G. and J.B. All authors have read and agreed to the published version of the manuscript.

Funding: This work was supported by a grant (A.R.Y.) from the Heart Center intramural program (51108-0005-1219) at Nationwide Children's Hospital.

Institutional Review Board Statement: Not applicable.

Informed Consent Statement: Not applicable.

Data Availability Statement: Not applicable.

Conflicts of Interest: The authors declare no conflict of interest.

\section{References}

1. Roger, V.L. Epidemiology of heart failure. Circ. Res. 2013, 113, 646-659. [CrossRef] [PubMed]

2. Ziaeian, B.; Fonarow, G.C. Epidemiology and aetiology of heart failure. Nat. Rev. Cardiol. 2016, 13, 368-378. [CrossRef]

3. Shaddy, R.E.; George, A.T.; Jaecklin, T.; Lochlainn, E.N.; Thakur, L.; Agrawal, R.; Solar-Yohay, S.; Chen, F.; Rossano, J.W.; Severin, T.; et al. Systematic Literature Review on the Incidence and Prevalence of Heart Failure in Children and Ado-lescents. Pediatr. Cardiol. 2018, 39, 415-436. [CrossRef]

4. Jenks, C.L.; Raman, L.; Dalton, H.J. Pediatric Extracorporeal Membrane Oxygenation. Crit. Care Clin. 2017, 33, 825-841. [CrossRef]

5. Huang, S.-C.; Wu, E.-T.; Ko, W.-J.; Lai, L.-P.; Hsu, J.; Chang, C.-I.; Chiu, I.-S.; Wang, S.-S.; Wu, M.-H.; Lin, F.-Y.; et al. Clinical Implication of Blood Levels of B-Type Natriuretic Peptide in Pediatric Patients on Mechanical Circulatory Support. Ann. Thorac. Surg. 2006, 81, 2267-2272. [CrossRef] [PubMed]

6. Auer, J.; Weber, T. The Diagnostic and Prognostic Value of Brain Natriuretic Peptide and Aminoterminal (nt)-pro Brain Natriuretic Peptide. Curr. Pharm. Des. 2005, 11, 511-525. [CrossRef]

7. Karam, S.; Moores, R.; Rozycki, H.; Astoria, M. Cardiac Troponin Levels in Neonates Who Require ECMO for Noncardiac Indications Are Elevated in Nonsurvivors. Am. J. Perinatol. 2015, 32, 859-864. [CrossRef] [PubMed]

8. Papathanasiou, M.; Pizanis, N.; Tsourelis, L.; Koch, A.; Kamler, M.; Rassaf, T.; Luedike, P. Dynamics and prognostic value of B-type natriuretic peptide in left ventricular assist device recipients. J. Thorac. Dis. 2019, 11, 138-144. [CrossRef]

9. Erkilet, G.; Schulte-Eistrup, S.; Morshuis, M.; Bohms, B.; Roefe, D.; Gummert, J.; Milting, H. Plasma galectin 3 is increased in terminal heart failure patients and is elevated in patients not surviving mechanical circulatory support. J. Heart Lung Transplant. 2010, 29, S65. [CrossRef]

10. Lee, C.S.; Mudd, J.O.; Lyons, K.S.; Denfeld, Q.E.; Jurgens, C.Y.; Aouizerat, B.E.; Gelow, J.M.; Chien, C.V.; Aarons, E.; Grady, K.L. Heart Failure Symptom Biology in Response to Ventricular Assist Device Implantation. J. Cardiovasc. Nurs. 2019, 34, 174-182. [CrossRef]

11. Li, Y.; McTiernan, C.F.; Pei, W.; Moravec, C.S.; Wang, P.; Rosenblum, W.; Kormos, R.L.; Feldman, A.M. Downregulation of matrix metalloproteinases and reduction in collagen damage in the failing human heart after support with left ventricular assist devices kmar. Circulation 2001, 104, 1147-1152. [CrossRef] [PubMed] 
12. Bruggink, A.H.; Van Oosterhout, M.F.M.; De Jonge, N.; Cleutjens, J.P.M.; Van Wichen, D.F.; Van Kuik, J.; Tilanus, M.G.J.; GmeligMeyling, F.H.J.; Tweel, J.G.V.D.; De Weger, R.A. Type IV collagen degradation in the myocardial basement membrane after unloading of the failing heart by a left ventricular assist device. Lab. Investig. 2007, 87, 1125-1137. [CrossRef] [PubMed]

13. Schipper, M.E.; Scheenstra, M.R.; Van Kuik, J.; Van Wichen, D.F.; Van Der Weide, P.; Dullens, H.F.; Lahpor, J.; De Jonge, N.; De Weger, R.A. Osteopontin: A potential biomarker for heart failure and reverse remodeling after left ventricular assist device support. J. Hear. Lung Transpl. 2011, 30, 805-810. [CrossRef] [PubMed]

14. Luyt, C.-E.; Landivier, A.; Leprince, P.; Bernard, M.; Pavie, A.; Chastre, J.; Combes, A. Usefulness of cardiac biomarkers to predict cardiac recovery in patients on extracorporeal membrane oxygenation support for refractory cardiogenic shock. J. Crit. Care 2012, 27, 524.e7-524.e14. [CrossRef] [PubMed]

15. Kramer, F.; Milting, H. Novel biomarkers in human terminal heart failure and under mechanical circulatory support. Biomarkers 2011, 16, S31-S41. [CrossRef] [PubMed]

16. Ragusa, R.; Prontera, C.; Di Molfetta, A.; Cabiati, M.; Masotti, S.; Del Ry, S.; Amodeo, A.; Trivella, M.G.; Clerico, A.; Caselli, C. Time-course of circulating cardiac and inflammatory biomarkers after Ventricular Assist Device implan-tation: Comparison between paediatric and adult patients. Clin. Chim. Acta 2018, 486, 88-93. [CrossRef] [PubMed]

17. Emdin, M.; Aimo, A.; Vergaro, G.; Bayes-Genis, A.; Lupón, J.; Latini, R.; Meessen, J.; Anand, I.S.; Cohn, J.N.; Gravning, J.; et al. sST2 Predicts Outcome in Chronic Heart Failure Beyond NT-proBNP and High-Sensitivity Troponin T. J. Am. Coll. Cardiol. 2018, 72, 2309-2320. [CrossRef]

18. Milting, H.; Ellinghaus, P.; Seewald, M.; Cakar, H.; Bohms, B.; Kassner, A.; Körfer, R.; Klein, M.; Krahn, T.; Kruska, L.; et al. Plasma biomarkers of myocardial fibrosis and remodeling in terminal heart failure patients supported by mechanical circulatory support devices. J. Heart Lung Transpl. 2008, 27, 589-596. [CrossRef] [PubMed]

19. Elola, M.T.; Wolfenstein-Todel, C.; Troncoso, M.F.; Vasta, G.R.; Rabinovich, G.A. Galectins: Matricellular glycan-binding proteins linking cell adhesion, migration, and survival. Cell. Mol. Life Sci. 2007, 64, 1679-1700. [CrossRef]

20. Hughes, R.C. The galectin family of mammalian carbohydrate-binding molecules. Biochem. Soc. Trans. 1997, 25, 1194-1198. [CrossRef]

21. Meijers, W.C.; Van Der Velde, A.R.; De Boer, R.A. The ARCHITECT galectin-3 assay: Comparison with other automated and manual assays for the measurement of circulating galectin-3 levels in heart failure. Expert Rev. Mol. Diagn. 2014, 14, 257-266. [CrossRef] [PubMed]

22. Papaspyridonos, M.; McNeill, E.; de Bono, J.P.; Smith, A.; Burnand, K.G.; Channon, K.M.; Greaves, D.R. Galectin-3 is an amplifier of inflammation in atherosclerotic plaque progression through mac-rophage activation and monocyte chemoattraction. Arterioscler. Thromb. Vasc. Biol 2008, 28, 433-440. [CrossRef] [PubMed]

23. Zhuo, Y.; Chammas, R.; Bellis, S.L. Sialylation of beta1 integrins blocks cell adhesion to galectin-3 and protects cells against galectin-3-induced apoptosis. J. Biol. Chem. 2008, 283, 22177-22185. [CrossRef] [PubMed]

24. Henderson, N.C.; MacKinnon, A.C.; Farnworth, S.L.; Kipari, T.; Haslett, C.; Iredale, J.P.; Liu, F.-T.; Hughes, J.; Sethi, T. Galectin-3 Expression and Secretion Links Macrophages to the Promotion of Renal Fibrosis. Am. J. Pathol. 2008, 172, 288-298. [CrossRef] [PubMed]

25. Yang, E.; Shim, J.S.; Woo, H.-J.; Kim, K.-W.; Kwon, H.J. Aminopeptidase N/CD13 induces angiogenesis through interaction with a pro-angiogenic protein, galectin-3. Biochem. Biophys. Res. Commun. 2007, 363, 336-341. [CrossRef] [PubMed]

26. Martínez-Martínez, E.; Brugnolaro, C.; Ibarrola, J.; Ravassa, S.; Buonafine, M.; López, B.; Fernández-Celis, A.; Querejeta, R.; Santamaria, E.; Fernández-Irigoyen, J.; et al. CT-1 (Cardiotrophin-1)-Gal-3 (Galectin-3) Axis in Cardiac Fibrosis and Inflammation. Hypertension 2019, 73, 602-611. [CrossRef]

27. Martínez-Martínez, E.; Ibarrola, J.; Fernández-Celis, A.; Santamaria, E.; Fernández-Irigoyen, J.; Rossignol, P.; Jaisser, F.; LopezAndres, N. Differential Proteomics Identifies Reticulocalbin-3 as a Novel Negative Mediator of Collagen Production in Human Cardiac Fibroblasts. Sci. Rep. 2017, 7, 1-10. [CrossRef]

28. Tyminska, A.; Kapłon-Cieślicka, A.; Ozierański, K.; Budnik, M.; Wancerz, A.; Sypień, P.; Peller, M.; Balsam, P.; Opolski, G.; Filipiak, K.J. Association of Galectin-3 and Soluble ST2, and Their Changes, with Echocardiographic Parameters and Development of Heart Failure after ST-Segment Elevation Myocardial Infarction. Dis. Markers 2019, 2019, 9529053. [CrossRef]

29. Opotowsky, A.; Baraona, F.; Owumi, J.; Loukas, B.; Singh, M.N.; Valente, A.M.; Wu, F.; Cheng, S.; Veldtman, G.; Rimm, E.B.; et al. Galectin-3 Is Elevated and Associated with Adverse Outcomes in Patients with Single-Ventricle Fontan Circulation. J. Am. Hear. Assoc. 2016, 5, e002706. [CrossRef]

30. Mosleh, W.; Kattel, S.; Bhatt, H.; Al-Jebaje, Z.; Khan, S.; Shah, T.; Dahal, S.; Khalil, C.; Frodey, K.; Elibol, J.; et al. Galectin-3 as a Risk Predictor of Mortality in Survivors of Out-of-Hospital Cardiac Arrest. Circ. Arrhythmia Electrophysiol. 2019, 12, e007519. [CrossRef]

31. Van Kimmenade, R.R.; Januzzi, J.L., Jr.; Ellinor, P.T.; Sharma, U.C.; Bakker, J.A.; Low, A.F.; Martinez, A.; Crijns, H.J.; MacRae, C.A.; Menheere, P.P.; et al. Utility of amino-terminal pro-brain natriuretic peptide, galectin-3, and apelin for the evaluation of patients with acute heart failure. J. Am. Coll. Cardiol. 2006, 48, 1217-1224. [CrossRef] [PubMed]

32. Sygitowicz, G.; Tomaniak, M.; Filipiak, K.J.; Kołtowski, Ł.; Sitkiewicz, D. Galectin-3 in Patients with Acute Heart Failure: Preliminary Report on First Polish Experience. Adv. Clin. Exp. Med. 2016, 25, 617-623. [CrossRef] [PubMed] 
33. George, M.; Shanmugam, E.; Srivatsan, V.; Vasanth, K.; Ramraj, B.; Rajaram, M.; Jena, A.; Sridhar, A.; Chaudhury, M.; Kaliappan, I. Value of pentraxin-3 and galectin-3 in acute coronary syndrome: A short-term prospective cohort study. Ther. Adv. Cardiovasc. Dis. 2015, 9, 275-284. [CrossRef] [PubMed]

34. McEvoy, J.W.; Chen, Y.; Halushka, M.K.; Christenson, E.; Ballantyne, C.M.; Blumenthal, R.S.; Christenson, R.H.; Selvin, E. Galectin-3 and Risk of Heart Failure and Death in Blacks and Whites. J. Am. Hear Assoc. 2016, 5, e003079. [CrossRef]

35. Ueland, T.; Aukrust, P.; Broch, K.; Aakhus, S.; Skårdal, R.; Muntendam, P.; Gullestad, L. Galectin-3 in heart failure: High levels are associated with all-cause mortality. Int. J. Cardiol. 2011, 150, 361-364. [CrossRef]

36. Coromilas, E.; Que-Xu, E.-C.; Moore, D.; Kato, T.S.; Wu, C.; Ji, R.; Givens, R.; Jorde, U.P.; Takayama, H.; Naka, Y.; et al. Dynamics and prognostic role of galectin-3 in patients with advanced heart failure, during left ventricular assist device support and following heart transplantation. BMC Cardiovasc. Disord. 2016, 16, 1-10. [CrossRef]

37. Erkilet, G.; Özpeker, C.; Böthig, D.; Kramer, F.; Röfe, D.; Bohms, B.; Morshuis, M.; Gummert, J.; Milting, H. The biomarker plasma galectin-3 in advanced heart failure and survival with mechanical circulatory support devices. J. Hear. Lung Transpl. 2013, 32, 221-230. [CrossRef]

38. Kotby, A.A.; Youssef, O.I.; Elmaraghy, M.O.; El Sharkawy, O.S. Galectin-3 in Children with Chronic Heart Failure with Normal and Reduced Ejection Fraction: Rela-tionship to Disease Severity. Pediatr. Cardiol. 2017, 38, 95-102. [CrossRef]

39. Saleh, N.; Khattab, A.; Rizk, M.; Salem, S.; Abo-Haded, H. Value of Galectin-3 assay in children with heart failure secondary to congenital heart diseases: A prospective study. BMC Pediatr. 2020, 20, 1-9. [CrossRef]

40. Lok, S.I.; Nous, F.M.; Van Kuik, J.; Van Der Weide, P.; Winkens, B.; Kemperman, H.; Huisman, A.; Lahpor, J.R.; De Weger, R.A.; De Jonge, N. Myocardial fibrosis and pro-fibrotic markers in end-stage heart failure patients during continuous-flow left ventricular assist device support. Eur. J. Cardiothorac. Surg. 2015, 48, 407-415. [CrossRef]

41. Ahmad, T.; Wang, T.; O’Brien, E.C.; Samsky, M.D.; Pura, J.A.; Lokhnygina, Y.; Rogers, J.G.; Hernandez, A.F.; Craig, D.; Bowles, D.E.; et al. Effects of Left Ventricular Assist Device Support on Biomarkers of Cardiovascular Stress, Fibrosis, Fluid Homeostasis, Inflammation, and Renal Injury. JACC Hear Fail. 2015, 3, 30-39. [CrossRef]

42. Miller, A.M.; Xu, D.; Asquith, D.L.; Denby, L.; Li, Y.; Sattar, N.; Baker, A.H.; McInnes, I.B.; Liew, F.Y. IL-33 reduces the development of atherosclerosis. J. Exp. Med. 2008, 205, 339-346. [CrossRef]

43. Pascual-Figal, D.A.; Januzzi, J.L. The Biology of ST2: The International ST2 Consensus Panel. Am. J. Cardiol. 2015, 115, 3B-7B. [CrossRef] [PubMed]

44. Sabatine, M.S.; Morrow, D.A.; Higgins, L.J.; MacGillivray, C.; Guo, W.; Bode, C.; Rifai, N.; Cannon, C.P.; Gerszten, R.E.; Lee, R.T. Complementary Roles for Biomarkers of Biomechanical Strain ST2 and N-Terminal Prohormone B-Type Natriuretic Peptide in Patients With ST-Elevation Myocardial Infarction. Circulation 2008, 117, 1936-1944. [CrossRef]

45. Farcaş, A.D.; Mocan, M.; Anton, F.P.; Hognogi, L.D.M.; Chiorescu, R.M.; Stoia, M.A.; Vonica, C.L.; Goidescu, C.M.; Vida-Simiti, L.A. Short-Term Prognosis Value of sST2 for an Unfavorable Outcome in Hypertensive Patients. Dis. Markers 2020, $2020,8143737$. [CrossRef] [PubMed]

46. Tang, W.W.; Wu, Y.; Grodin, J.L.; Hsu, A.P.; Hernandez, A.F.; Butler, J.; Metra, M.; Voors, A.A.; Felker, G.M.; Troughton, R.W.; et al. Prognostic Value of Baseline and Changes in Circulating Soluble ST2 Levels and the Effects of Nesiritide in Acute Decompensated Heart Failure. JACC Hear Fail. 2016, 4, 68-77. [CrossRef] [PubMed]

47. Gaggin, H.K.; Motiwala, S.; Bhardwaj, A.; Parks, K.A.; Januzzi, J.L., Jr. Soluble concentrations of the interleukin receptor family member ST2 and beta-blocker therapy in chronic heart failure. Circ. Heart Fail 2013, 6, 1206-1213. [CrossRef]

48. Patel, D.M.; Thiessen-Philbrook, H.; Brown, J.R.; McArthur, E.; Moledina, D.G.; Mansour, S.G.; Shlipak, M.G.; Koyner, J.L.; Kavsak, P.; Whitlock, R.P.; et al. Association of plasma-soluble ST2 and galectin-3 with cardiovascular events and mortality following cardiac surgery. Am. Hear. J. 2020, 220, 253-263. [CrossRef]

49. Tseng, C.C.S.; Huibers, M.M.H.; Gaykema, L.H.; Koning, E.S.-D.; Ramjankhan, F.Z.; Maisel, A.S.; De Jonge, N. Soluble ST2 in end-stage heart failure, before and after support with a left ventricular assist device. Eur. J. Clin. Investig. 2018, 48 , e12886. [CrossRef]

50. De Boer, R.A.; Voors, A.A.; Muntendam, P.; van Gilst, W.H.; van Veldhuisen, D.J. Galectin-3: A novel mediator of heart failure development and progression. Eur. J. Heart Fail. 2009, 11, 811-817. [CrossRef]

51. Chow, S.L.; Maisel, A.S.; Anand, I.; Bozkurt, B.; De Boer, R.A.; Felker, G.M.; Fonarow, G.C.; Greenberg, B.; Januzzi, J.L.; Kiernan, M.S.; et al. Role of Biomarkers for the Prevention, Assessment, and Management of Heart Failure: A Scientific Statement from the American Heart Association. Circulation 2017, 135, e1054-e1091. [CrossRef] [PubMed]

52. Mueller, T.; Dieplinger, B. Soluble ST2 and Galectin-3: What We Know and Don't Know Analytically. EJIFCC 2016, $27,224-237$.

53. Rehman, S.U.; Mueller, T.; Januzzi, J.L., Jr. Characteristics of the novel interleukin family biomarker ST2 in atients with acute heart failure. J Am Coll Cardiol. 2008, 52, 1458-1465. [CrossRef] [PubMed]

54. Henderson, N.C.; MacKinnon, A.C.; Farnworth, S.L.; Poirier, F.; Russo, F.P.; Iredale, J.P.; Haslett, C.; Simpson, K.J.; Sethi, T. Galectin-3 regulates myofibroblast activation and hepatic fibrosis. Proc. Natl. Acad. Sci. USA 2006, 103, 5060-5065. [CrossRef]

55. Nishi, Y.; Sano, H.; Kawashima, T.; Okada, T.; Kuroda, T.; Kikkawa, K.; Kawashima, S.; Tanabe, M.; Goto, T.; Matsuzawa, Y.; et al. Role of Galectin-3 in Human Pulmonary Fibrosis. Allergol. Int. 2007, 56, 57-65. [CrossRef] [PubMed]

56. Jourdain, P.; Jondeau, G.; Funck, F.; Gueffet, P.; Le Helloco, A.; Donal, E.; Aupetit, J.F.; Aumont, M.C.; Galinier, M.; Eicher, J.C.; et al. Plasma brain natriuretic peptide-guided therapy to improve outcome in heart failure: The STARS-BNP Multicenter Study. J. Am. Coll. Cardiol. 2007, 49, 1733-1739. [CrossRef] [PubMed] 
57. Sanders-van Wijk, S.; van Asselt, A.D.; Rickli, H.; Estlinbaum, W.; Erne, P.; Rickenbacher, P.; Vuillomenet, A.; Peter, M.; Pfisterer, M.E.; Brunner-La Rocca, H.P. Cost-effectiveness of N-terminal pro-B-type natriuretic-guided therapy in elderly heart failure patients: Results from TIME-CHF (Trial of Intensified versus Standard Medical Therapy in Elderly Patients with Congestive Heart Failure). JACC Heart Fail 2013, 1, 64-71. [CrossRef]

58. Eurlings, L.W.; van Pol, P.E.; Kok, W.E.; van Wijk, S.; Lodewijks-van der Bolt, C.; Balk, A.H.; Lok, D.J.; Crijns, H.J.; van Kraaij, D.J.; de Jonge, N.; et al. Management of chronic heart failure guided by individual N-terminal pro-B-type natriuretic peptide targets: Results of the PRIMA (Can PRo-brain-natriuretic peptide guided therapy of chronic heart failure IMprove heart fAilure morbidity and mortality?) study. J. Am. Coll. Cardiol. 2010, 56, 2090-2100.

59. Lainchbury, J.G.; Troughton, R.W.; Strangman, K.M.; Frampton, C.M.; Pilbrow, A.; Yandle, T.G.; Hamid, A.K.; Nicholls, M.G.; Richards, A.M. N-terminal pro-B-type natriuretic peptide-guided treatment for chronic heart failure: Results from the BATTLESCARRED (NT-proBNP-Assisted Treatment to Lessen Serial Cardiac Readmissions and Death) trial. J. Am. Coll. Cardiol. 2009, 55, 53-60. [CrossRef]

60. Pfisterer, M.; Buser, P.; Rickli, H.; Gutmann, M.; Erne, P.; Rickenbacher, P.; Vuillomenet, A.; Jeker, U.; Dubach, P.; Beer, H.; et al. BNP-guided vs symptom-guided heart failure therapy: The Trial of Intensified vs Standard Medical Therapy in Elderly Patients With Congestive Heart Failure (TIME-CHF) randomized trial. J. Am. Med. Assoc. 2009, 301, 383-392. [CrossRef]

61. Delaine, T.; Collins, P.; MacKinnon, A.; Sharma, G.; Stegmayr, J.; Rajput, V.K.; Mandal, S.; Cumpstey, I.; Larumbe, A.; Salameh, B.A.; et al. Galectin-3-Binding Glycomimetics that Strongly Reduce Bleomycin-Induced Lung Fibrosis and Modulate Intracellular Glycan Recognition. ChemBioChem 2016, 17, 1759-1770. [CrossRef] [PubMed]

62. Zetterberg, F.; Peterson, K.; Johnsson, R.E.; Brimert, T.; Håkansson, M.; Logan, D.T.; Leffler, H.; Nilsson, U.J. Monosaccharide Derivatives with Low-Nanomolar Lectin Affinity and High Selectivity Based on Combined Fluorine-Amide, Phenyl-Arginine, Sulfur- $\pi$, and Halogen Bond Interactions. ChemMedChem 2018, 13, 133-137. [CrossRef] [PubMed]

63. Stegmayr, J.; Zetterberg, F.; Carlsson, M.C.; Huang, X.; Sharma, G.; Kahl-Knutson, B.; Schambye, H.; Nilsson, U.J.; Oredsson, S.; Leffler, H. Extracellular and intracellular small-molecule galectin-3 inhibitors. Sci. Rep. 2019, 9, 1-12. [CrossRef] [PubMed]

64. Prud'Homme, M.; Coutrot, M.; Michel, T.; Boutin, L.; Genest, M.; Poirier, F.; Launay, J.-M.; Kane, B.; Kinugasa, S.; Prakoura, N.; et al. Acute Kidney Injury Induces Remote Cardiac Damage and Dysfunction Through the Galectin-3 Pathway. JACC Basic Transl. Sci. 2019, 4, 717-732. [CrossRef] [PubMed]

65. Zhang, J.; Ramadan, A.M.; Griesenauer, B.; Li, W.; Turner, M.J.; Liu, C.; Kapur, R.; Hanenberg, H.; Blazar, B.R.; Tawara, I.; et al. ST2 blockade reduces sST2-producing T cells while maintaining protective mST2-expressing T cells during graft-versus-host disease. Sci. Transl. Med. 2015, 7, 308ra160. [CrossRef]

66. Fursov, N.; Johnston, E.; Duffy, K.; Cotty, A.; Petley, T.; Fisher, J.; Jiang, H.; Rycyzyn, M.A.; Giles-Komar, J.; Powers, G. Generation and Characterization of Rat Anti-mouse ST2L Monoclonal Antibodies. Hybrid 2011, 30, 153-162. [CrossRef]

67. Naruke, T.; Inomata, T.; Imai, H.; Yanagisawa, T.; Maekawa, E.; Mizutani, T.; Osaka, T.; Shinagawa, H.; Koitabashi, T.; Nishii, M.; et al. End-tidal carbon dioxide concentration can estimate the appropriate timing for weaning off from extra-corporeal membrane oxygenation for refractory circulatory failure. Int. Heart J. 2010, 51, 116-120. [CrossRef]

68. Wang, C.-H.; Yang, N.-I.; Liu, M.-H.; Hsu, K.-H.; Kuo, L.-T. Estimating systemic fibrosis by combining galectin-3 and ST2 provides powerful risk stratification value for patients after acute decompensated heart failure. Cardiol. J. 2013, 23, 563-572. [CrossRef]

69. Rosa, S.; Eposito, F.; Carella, C.; Strangio, A.; Ammirati, G.; Sabatino, J.; Abbate, F.G.; Iaconetti, C.; Liguori, V.; Pergola, V.; et al. Transcoronary concentration gradients of circulating microRNAs in heart failure. Eur. J. Heart Fail. 2018, 20, 1000-1010. [CrossRef]

70. Barsanti, C.; Trivella, M.G.; D’Aurizio, R.; El Baroudi, M.; Baumgart, M.; Groth, M.; Caruso, R.; Verde, A.; Botta, L.; Cozzi, L.; et al. Differential Regulation of MicroRNAs in End-Stage Failing Hearts Is Associated with Left Ventricular Assist Device Unloading. BioMed Res. Int. 2015, 2015, 592512. [CrossRef]

71. Lok, S.I.; De Jonge, N.; Van Kuik, J.; Van Geffen, A.J.P.; Huibers, M.M.H.; Van Der Weide, P.; Siera, E.; Winkens, B.; Doevendans, P.A.; De Weger, R.A.; et al. MicroRNA Expression in Myocardial Tissue and Plasma of Patients with End-Stage Heart Failure during LVAD Support: Comparison of Continuous and Pulsatile Devices. PLoS ONE 2015, 10, e0136404. [CrossRef] [PubMed]

72. Akat, K.M.; Moore-McGriff, D.; Morozov, P.; Brown, M.; Gogakos, T.; Da Rosa, J.C.; Mihailovic, A.; Sauer, M.; Ji, R.; Ramarathnam, A.; et al. Comparative RNA-sequencing analysis of myocardial and circulating small RNAs in human heart failure and their utility as biomarkers. Proc. Natl. Acad. Sci. USA 2014, 111, 11151-11156. [CrossRef] [PubMed] 